\title{
Effect of active packaging atmosphere on the shelf life of chilled stored steaks of barracuda Sphyraena jello
}

\author{
S. REMYA ${ }^{1}$, C. O. MOHAN ${ }^{2}$, C. N. RAVISHANKAR ${ }^{2}$, G. K. SIVARAMAN ${ }^{1}$, A. K. JHA ${ }^{1}$ \\ AND G. VENKATESHWARLU3 \\ ${ }^{1}$ Veraval Regional Centre of ICAR-Central Institute of Fisheries Technology, Veraval-362 269, Gujarat, India \\ ${ }^{2}$ ICAR-Central Institute of Fisheries Technology, Kochi - 682 029, Kerala, India \\ ${ }^{3}$ Indian Council of Agricultural Research, New Delhi -110 001, India \\ e-mail: remya03cof@gmail.com
}

\begin{abstract}
In the present study, effect of an active reduced oxygen packaging atmosphere on the shelf life of barracuda (Sphyraena jello) fish steaks stored at $0-2^{\circ} \mathrm{C}$ was analysed. Barracuda steaks of $2.5 \mathrm{~cm}$ were divided into two batches; the first batch served as control, which was aerobically packed (AP) inside a multilayer film pouch of ethylene-vinyl alcohol (EVOH) with high barrier properties and the second batch packed in EVOH pouch was attached with a commercial oxygen $\left(\mathrm{O}_{2}\right)$ scavenger (OS). OS reduced the amount of $\mathrm{O}_{2}$ inside the package to less than $0.01 \%$ within $24 \mathrm{~h}$. On $12^{\text {th }}$ day of storage, there was a $2 \log$ difference in the total mesophilic count of steaks in OS attached pouches, compared to control. The $2 \mathrm{mg}$ malonaldehyde $\mathrm{kg}^{-1}$ limit of thiobarbituric acid (TBA) value, which is an index of secondary lipid oxidation, was exceeded in control, on $12^{\text {th }}$ day of chilled storage. Based on the sensory score, control was rejected on $12^{\text {th }}$ day, while OS steaks were acceptable till $20^{\text {th }}$ day. The results indicate that OS is efficient in enhancing the storage life of fish by limiting the oxygen present inside the package.
\end{abstract}

Keywords: Active packaging, Barracuda, Oxygen scavenger, Shelf life

\section{Introduction}

Fish, which is a rich source of $\omega-3$ poly unsaturated fatty acids (PUFA) and cheap protein, is a highly sought after food item worldwide. In 2010, global per capita fish consumption increased to $18.9 \mathrm{~kg}$ from an average of $9.9 \mathrm{~kg}$ in the 1960s (FAO, 2014), due to rapid population growth, increasing affluence and urbanisation. But, this preferred food spoils fast mainly because of microbial attack and oxidation of lipid, especially during long term storage. Since the rate of fish spoilage is highly temperature reliant, storing at low temperature is a very common and widely practiced fish preservation method (Sivertsvik et al., 2002). In general, fish stored at chilled temperature, has a shelf life of 1-2 weeks, depending on the species. There are several reports on illegal practices of treating fish with unapproved chemicals or using permitted chemicals in more than allowable quantity, to further enhance the shelf life of chilled stored fish. In the present era of knowledge explosion, consumers are becoming more and more aware about the health implications of eating food containing synthetic additives. Thus, there is a huge demand for preservative free, minimally processed, and safer food which has led to the revolutionary concept of active packaging.
Unlike traditional packages, which act only as inert physical barrier, new generation active packages are intended to interact with the food contained inside or the surrounding environment (Pereira de Abreu et al., 2012). A package becomes active, when the food, packaging and the nearby environment interact to lengthen the storage life of food, improving the sensory quality and/or food security (Suppakul et al., 2003). This innovative concept can enhance the functionality of packaging because of the incorporation of an active substance into the packing material (Appendini and Hotchkiss, 2002). Currently, important active packaging components, which are getting popular, are oxygen scavengers, antimicrobial agents, ethylene absorbers, moisture regulators and carbon dioxide emitters.

Oxygen scavenging is the most widely adopted active packaging concept. Oxygen $\left(\mathrm{O}_{2}\right)$ is apparently one of the major reasons for fish spoilage because presence of oxygen causes oxidation of fish lipid and creates conducive atmosphere for the growth of aerobic microorganisms. Hence, restricting the amount of oxygen available in the package may enhance the storage life of extremely perishable foods like fish (Stiles, 1991). Most of the recognised $\mathrm{O}_{2}$ scavengers are in the form of small sachets, 
which contain different iron based powders combined with an appropriate catalyst. These kinds of scavengers usually react with moisture present in the food to produce a reactive hydrated metallic reducing agent that scavenges $\mathrm{O}_{2}$ within the food package and permanently converts it to a stable oxide (Ozdemir and Floros, 2004). There are many advantages in using such oxygen scavengers. It simplifies the process of reducing the concentration of gases inside the package and also minimises the costs of equipment involved in other reduced oxygen packaging methods (vacuum and modified atmosphere packaging). They are efficient in bringing down $\mathrm{O}_{2}$ level to $<0.01 \%$ (Alvarez, 2000), which is much lesser than the usual $0.3-3.0 \%$ residual $\mathrm{O}_{2}$ concentration attainable by modified atmosphere packaging. In spite of all these, there are a very few attempts to enhance the shelf life of fish by storing it in an active packaging atmosphere created using oxygen scavengers. Considering the above facts, the present study was aimed to improve the shelf life of barracuda (Sphyraena jello) fish steaks stored at $0-2^{\circ} \mathrm{C}$ using oxygen scavengers.

\section{Materials and methods}

Packaging and storage of barracuda fish steaks

Good quality barracuda (Sphyraena jello) fish was purchased from Veraval landing centre in Gujarat (India) and carried to the fish processing laboratory, with ice in $1: 1$ ratio. After reaching the laboratory, within half an hour, the fish were washed thoroughly and after beheading, gutting and cleaning, cut into steaks of $2.5 \mathrm{~cm}$ length and $50 \pm 5 \mathrm{~g}$ weight. The washed fish steaks were further randomly made into two batches. The first batch was packed under air (AP) inside multilayered plastic film pouch, which was made of EVOH (ethylene-vinyl alcohol) with nylon and polyethylene. The pouch was of $15 \times 20 \mathrm{~cm}$ size and the thickness of the film was around $140 \mu \mathrm{m}$ with an oxygen transmission rate of $3.86 \mathrm{ml} \mathrm{m}^{-2} 24 \mathrm{~h}^{-1}$ at 1 atmospheric pressure. The second batch of steaks (OS) was packed in EVOH pouch and a commercial $\mathrm{O}_{2}$ scavenger (ZPT 200 EC, Ageless ${ }^{\circledR}$, Mitsubishi Gas Chemical Company, Japan) with an $\mathrm{O}_{2}$ absorption ability of $200 \mathrm{ml}$ was attached inside the pouch. One $\mathrm{O}_{2}$ scavenger sachet was placed inside the EVOH pouch containing one fish steak of $50 \pm 5 \mathrm{~g}$ weight. Pouches of both the batches were then heat sealed and stored at chilled temperature $\left(0-2^{\circ} \mathrm{C}\right)$. Three pouches from each batch were drawn at regular intervals and subjected to headspace gas composition, biochemical, microbiological and sensory quality analyses.

\section{Head space gas composition analysis}

The gas composition in the headspace of the pouch was determined on every sampling day, including the first four days continuously, using a Gas analyser (PBI
Dansensor CheckMate 9900, Denmark). A syringe needle piercing a rubber septum pasted on the $\mathrm{EVOH}$ pouch was used for drawing the gas in the headspace.

\section{Fish quality analysis}

$\mathrm{pH}$ was measured using a digital $\mathrm{pH}$ meter (Cyberscan 510, Eutech Instruments, Singapore) after homogenising the fish sample in distilled water $(1: 5 \mathrm{w} / \mathrm{v})$. Total volatile base nitrogen (TVB-N) and trimethylamine nitrogen (TMA-N) in the fish steak were determined by micro diffusion method (Conway, 1962). Primary and secondary lipid oxidation products in the samples were analysed by peroxide value (PV) (AOCS, 1989) and thiobarbituric acid (TBA) value (Tarladgis et al., 1960). Hydrolytic rancidity during chilled storage was evaluated by free fatty acid (FFA) value of barracuda fish steak (AOCS, 1989). Plate count agar (PCA) was used for enumerating total mesophilic (Townley and Lanier, 1981) and psychrotrophic (Hitching et al., 1995) counts of barracuda steaks by spread plate method. The inoculated plates were incubated at $37^{\circ} \mathrm{C}$ for $48 \mathrm{~h}$ and at $7^{\circ} \mathrm{C}$ for 5 days for total mesophilic counts and total psychrotrophic counts, respectively. A 9 point hedonic scale was used for organoleptic evaluation of the barracuda steaks. The sensory evaluation team had 6 regular members. They assigned a score of 9 for the most liked sample and 1 to the least liked sample (Meilgaard et al., 1999).

\section{Statistical analysis}

SPSS (Statistical Package for the Social Sciences Inc., Chicago, USA, Version 17) software was used for data analysis. Means were compared using oneway and two-way ANOVA. Duncan's Multiple Range Test (DMRT) was used for determining the significant difference between the treatments. For microbiological quality, the level of significance was set up at $p<0.01$ and for all other attributes, it was $\mathrm{p}<0.05$.

\section{Results and discussion}

Changes in the headspace gas $\left(\mathrm{O}_{2}\right.$ and $\left.\mathrm{CO}_{2}\right)$ composition

Headspace gas $\left(\mathrm{O}_{2}\right.$ and $\left.\mathrm{CO}_{2}\right)$ composition has been used as a useful indicator of microbial growth (Hurme, 2003). In the current study, there was a significant $(\mathrm{p}<0.05)$ difference in both $\mathrm{O}_{2}$ and $\mathrm{CO}_{2}$ concentration in the air and $\mathrm{O}_{2}$ scavenger packages, over the entire storage period (Fig. 1). Level of oxygen decreased to less than $0.01 \%$ within $24 \mathrm{~h}$, inside the package with $\mathrm{O}_{2}$ scavenger. The self triggering scavenger sachet enfolds iron based reactive compounds and the scavenging activity is due to iron oxidation. Similarly, decrease in $\mathrm{O}_{2}$ concentration was reported for rainbow trout fillets pre-treated with oregano essential oil and packed with $\mathrm{O}_{2}$ scavenger (Mexis et al., 2009), for catfish (Pangasius sutchi) steaks packed 


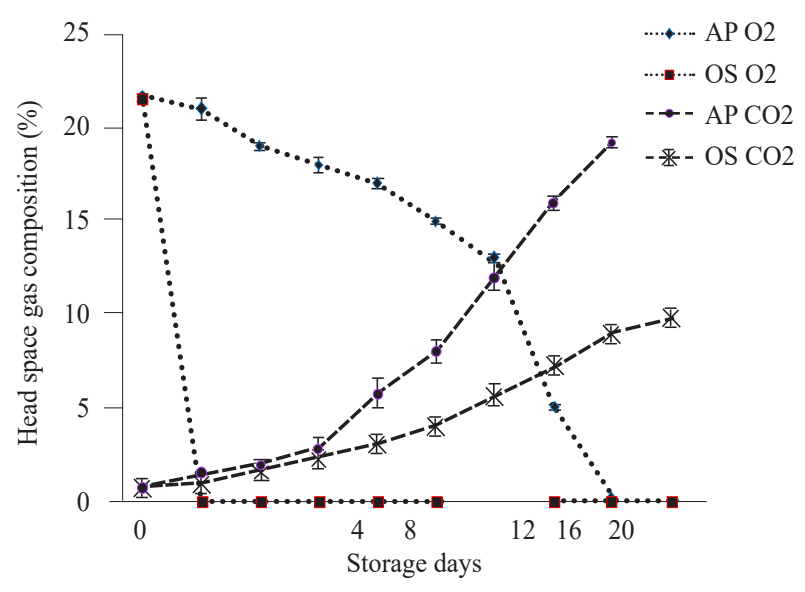

Fig. 1. Changes in the head space gas $\left(\mathrm{O}_{2}\right.$ and $\left.\mathrm{CO}_{2}\right)$ composition* of barracuda steaks packed under different atmospheric conditions. "Mean $\pm \mathrm{SD}, \mathrm{n}=3, \mathrm{p}<0.05$. AP: Air pack, OS: Pack with oxygen scavenger

with $\mathrm{O}_{2}$ scavenger (Mohan et al., 2008) and for gilthead seabream (Sparus aurata) packed with oxygen absorber (Goncalves et al., 2004). $\mathrm{O}_{2}$ content in aerobically packed barracuda steak samples also decreased slowly and reached $5 \%$ on $12^{\text {th }}$ day. Level of $\mathrm{CO}_{2}$ remained below $10 \%$ in $\mathrm{O}_{2}$ scavenger packs, till the end of the storage period. Contrary to that, it increased steadily from $0.7 \%$ (day 0) to $19.2 \%$ (day 16) in air packs. The reduction of $\mathrm{O}_{2}$ level and raise in $\mathrm{CO}_{2}$ level in air packages is reportedly due to the proliferation of aerobic bacteria, which utilise the $\mathrm{O}_{2}$ present in the package (Mohan et al., 2010). $\mathrm{CO}_{2}$ is produced in microbial metabolism and its accumulation in a package headspace is considered as a sign of microbial growth.

\section{Changes in the quality of barracuda steak during storage}

$\mathrm{pH}$ is used as an important factor to indicate the spoilage pattern of fish. In the current experiment, initial $\mathrm{pH}$ of barracuda steak was 6.1 (Fig. 2). In the early stages, $\mathrm{pH}$ decreased in aerobically packed sample and then increased steadily. Reduction of $\mathrm{pH}$ in the beginning is related to build up of lactic acid due to post-mortem breakdown of glycogen and could also be due to the $\mathrm{CO}_{2}$ content in the packs. $\mathrm{CO}_{2}$ dissolves in the tissue liquid leading to acidification and eventually carbonic acid is formed (Mohan et al., 2008). The increase in $\mathrm{pH}$ in later period is presumably due to the growth of spoilage bacteria leading to the production of volatile basic amines (Pastoriza et al., 1996). Barracuda steaks packed with and without $\mathrm{O}_{2}$ scavenger had significant $(\mathrm{p}<0.05)$ difference in the $\mathrm{pH}$ values during storage. Samples packed under reduced oxygen atmosphere showed slower increase in $\mathrm{pH}$ indicating that the use of $\mathrm{O}_{2}$ scavenger inhibited

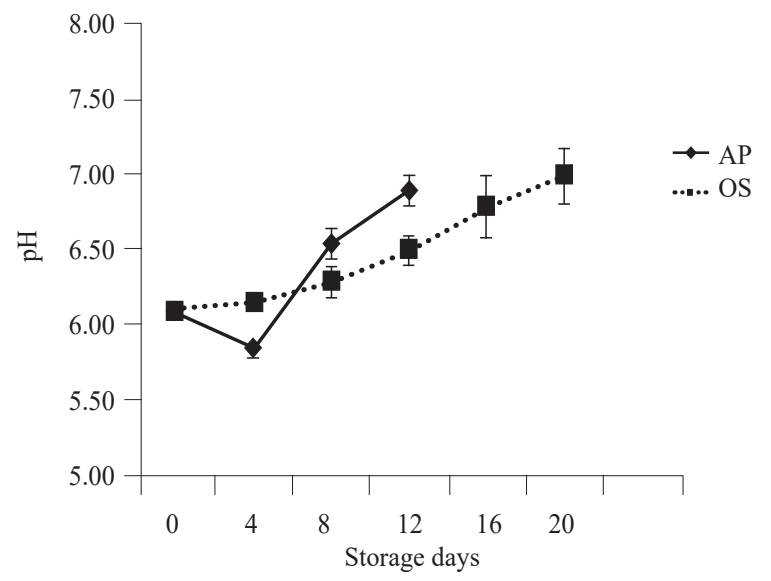

Fig. 2. Changes in the $\mathrm{pH}^{*}$ of barracuda steaks in different packs during chilled storage. AP: Air pack, OS: Pack with oxygen scavenger. "Mean $\pm \mathrm{SD}, \mathrm{n}=3, \mathrm{p}<0.05$

microbial growth and reduced the production of alkaline compounds.

Conventionally, the values of volatile base compounds, TVB-N and TMA-N, have been used as indicators to assess spoilage of fish products stored in ice. The initial TMA-N (Fig. 3) and TVB-N (Fig. 4) values of barracuda steak were 1.4 and $7.5 \mathrm{mg} \mathrm{N}_{2} 100 \mathrm{~g}^{-1}$, indicating good quality of the raw material used for the experiment. On $12^{\text {th }}$ day of chilled storage, the control sample exceeded the maximum acceptable limit of TMA-N, which is usually taken as 10-15 mg N $100 \mathrm{~g}^{-1}$ (Connell, 1995). TMA-N values of OS samples were below $10 \mathrm{mg} \mathrm{N}_{2} 100 \mathrm{~g}^{-1}$ till the end of storage period. The usual acceptable limit of TVB-N for fresh fish is $35-40 \mathrm{mg} \mathrm{N}_{2} 100 \mathrm{~g}^{-1}$ (Connell, 1990). The AP sample crossed this limit $\left(36.4 \mathrm{mg} \mathrm{N}_{2} 100 \mathrm{~g}^{-1}\right)$ on $12^{\text {th }}$ day of storage in ice, shortening its shelf life to only 12

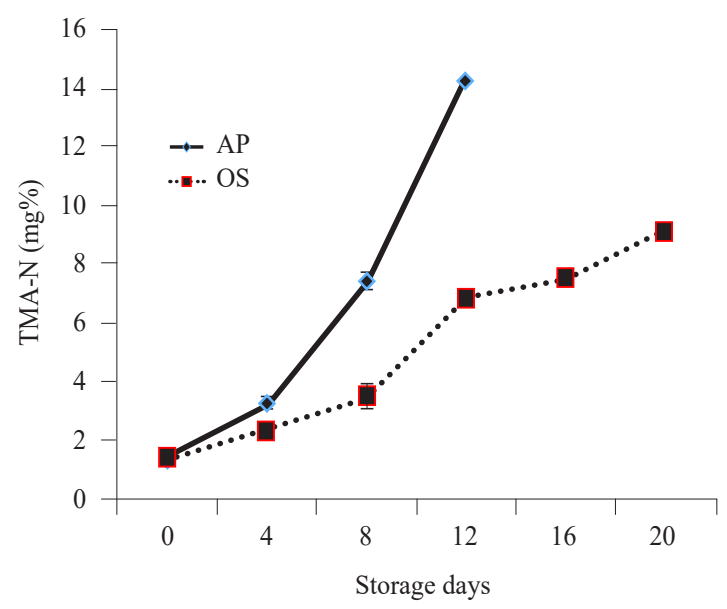

Fig. 3. Changes in the TMA-N value* of barracuda steaks in different packs during chilled storage. AP: Air pack, OS: Pack with oxygen scavenger. "Mean $\pm \mathrm{SD}, \mathrm{n}=3, \mathrm{p}<0.05$ 


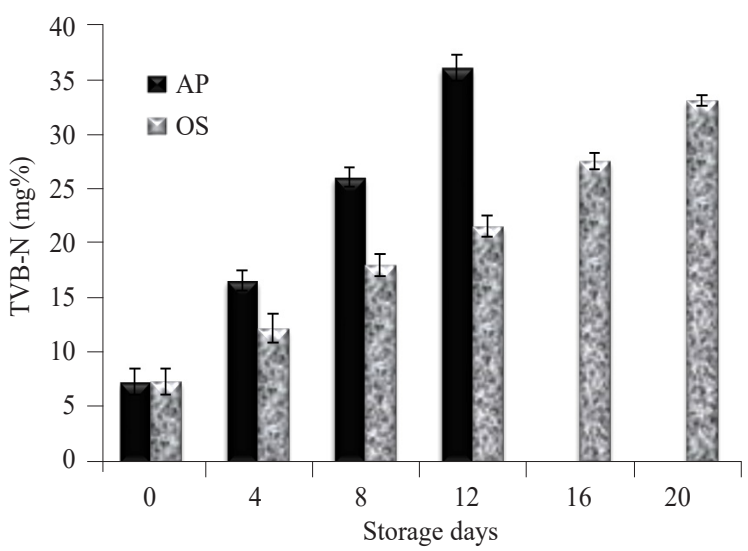

Fig. 4. Changes in the TVB-N value* of barracuda steaks during chilled storage. AP: Air pack, OS: Pack with oxygen scavenger. ${ }^{*}$ Mean $\pm \mathrm{SD}, \mathrm{n}=3, \mathrm{p}<0.05$

days while $\mathrm{O}_{2}$ scavenger significantly $(\mathrm{p}<0.05)$ delayed the TVB-N formation in OS sample. The $\mathrm{O}_{2}$ scavenger decreased the $\mathrm{O}_{2}$ concentration inside the package, which might have hindered the growth of aerobic bacteria and slowed down the formation of volatile basic amines (RuizCapillas and Moral, 2005). Similarly, lower TMA-N and TVB-N values were observed for $\mathrm{O}_{2}$ scavenger packed seer fish steaks (Mohan et al., 2009).

Lipid hydrolysis leads to the formation of free fatty acids in fish. Though it does not cause any loss of nutritional value, its increase will lead to reduction in the acceptability of fish by consumers (Aubourg et al., 1999). Therefore, FFA is quantified by many researchers to determine the sensory acceptability of food products (Barthet et al., 2008). The initial FFA value of barracuda steak as \% oleic acid was $1.7 \pm 0.15$, which rose to $8.5 \pm 0.14$ in AP (Fig. 5). The FFA value of aerobically packed sample was higher compared with samples packed under reduced oxygen atmosphere indicating the protective effect of $\mathrm{O}_{2}$

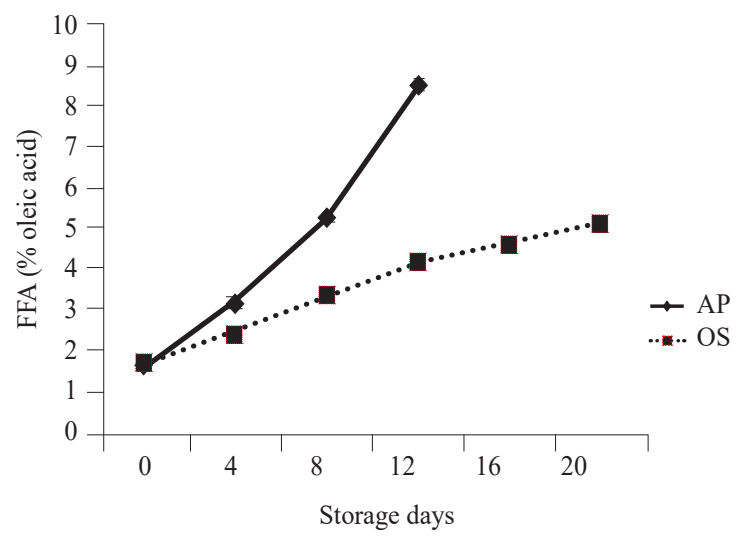

Fig. 5. Changes in the FFA value ${ }^{*}$ of barracuda steaks during chilled storage. AP: Air pack, OS: Pack with oxygen scavenger. ${ }^{*}$ Mean $\pm \mathrm{SD}, \mathrm{n}=3, \mathrm{p}<0.05$ scavenger. The final value of FFA on the day of sensory rejection in OS sample $\left(20^{\text {th }}\right.$ day) was $5.1 \pm 0.13 \%$ oleic acid.

Peroxide value (PV) is an indicator of the primary lipid oxidation products in fish. PV of fresh barracuda steak was 0.94 meq $\mathrm{O}_{2} \mathrm{~kg}^{-1}$ sample (Fig. 6). In the initial part of storage, all the samples showed a continuous increase in PV, which varied with the packing atmosphere and PV decreased in the later part of storage. Unsaturated fat in the samples breaks down into primary products of lipid oxidation (the peroxides and hydroperoxides) causing an initial steady increase in PV. Further, hydroperoxide degradation, generating secondary lipid oxidation products like malonaldehyde, leads to decrease in the level of primary oxidation products (Boselli et al., 2005). The control air sample showed a sharp increase in PV with storage time, whereas samples stored under reduced oxygen atmosphere had significantly $(p<0.05)$ lower increase in the PV. Similar result was obtained by previous study for catfish stored with $\mathrm{O}_{2}$ scavenger (Mohan et al., 2008).

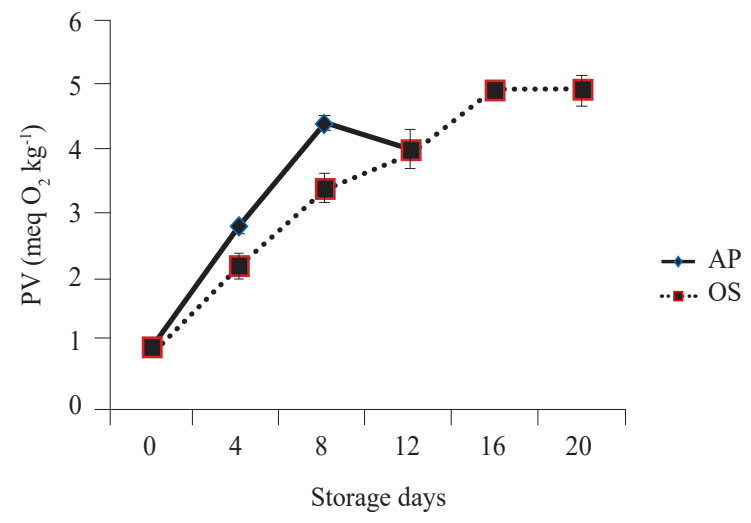

Fig. 6. Changes in the $\mathrm{PV}^{*}$ of barracuda steaks in different packs during chilled storage. AP: Air pack, OS: Pack with oxygen scavenger. *Mean $\pm \mathrm{SD}, \mathrm{n}=3, \mathrm{p}<0.05$

Thiobarbituric acid (TBA) value has been widely used to determine the secondary products of lipid oxidation. In the beginning, TBA value of barracuda steak was 0.32 mg malonaldehyde $\mathrm{kg}^{-1}$ (Fig. 7). TBA value of barracuda steaks increased during chilled storage with a lower increase in sample packed with $\mathrm{O}_{2}$ scavenger. Fish will usually have off-odour, when TBA value crosses 1-2 mg malonaldehyde $\mathrm{kg}^{-1}$ of fish flesh and is generally considered as the limit (Fan et al., 2009). The $2 \mathrm{mg}$ malonaldehyde $\mathrm{kg}^{-1}$ value was exceeded by control sample on $12^{\text {th }}$ day of storage while samples packed with $\mathrm{O}_{2}$ scavenger did not cross the limit till the end of storage. The higher increase in the TBA value of control could be due to exposure of sample to atmospheric oxygen entrapped in the air pack, which accelerates oxidation. In the same line, a reduction 


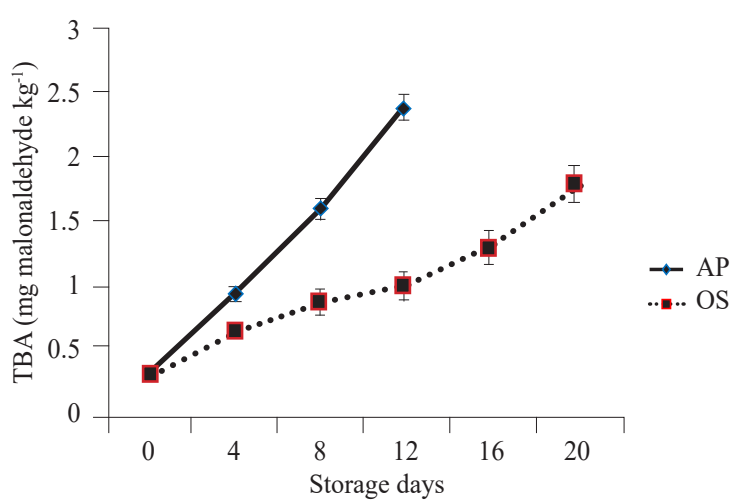

Fig. 7. Changes in the TBA value* of barracuda steaks in different packs during chilled storage. AP: Air pack, OS: Pack with oxygen scavenger. ${ }^{*}$ Mean $\pm \mathrm{SD}, \mathrm{n}=3, \mathrm{p}<0.05$

of malonaldehyde formation in sea bream packed with $\mathrm{O}_{2}$ absorber compared with air packed sample was reported (Goncalves et al., 2004).

In the beginning of the experiment, the total mesophilic (Fig. 8) and psychrotrophic counts (Fig. 9) of the barracuda steak were 3.3 and $2.5 \log \mathrm{cfu} \mathrm{g}^{-1}$, which increased over the period in fish steaks stored in different packaging environments. Initially, count of psychrotrophs recorded was less than mesophiles. As the storage of steaks progressed in ice, psychrotrophs dominated the bacterial flora due to rapid multiplication than mesophiles. At the end of the sensory life, psychrotrophic counts of AP and OS steaks were 8.2 and $7.6 \mathrm{log} \mathrm{cfu} \mathrm{g}^{-1}$. Ravishankar et al. (2008) also reported that psychrotrophic counts exceeded mesophilic counts in pearlspot samples stored at $0-2^{\circ} \mathrm{C}$, regardless of packaging atmosphere. The count of total mesophilic and psychrotrophic bacteria increased significantly $(p<0.01)$ in aerobically stored samples. The limit of $7 \log \mathrm{cfu} \mathrm{g}^{-1}$ of total mesophilic count was

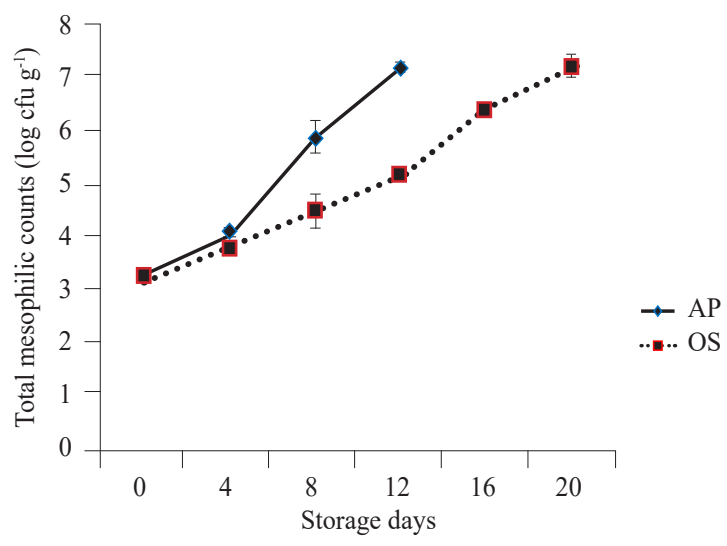

Fig. 8. Changes in the total mesophilic bacteria count* of barracuda steaks during chilled storage. AP: Air pack, OS: Pack with oxygen scavenger. ${ }^{*}$ Mean $\pm \mathrm{SD}, \mathrm{n}=3, \mathrm{p}<0.01$

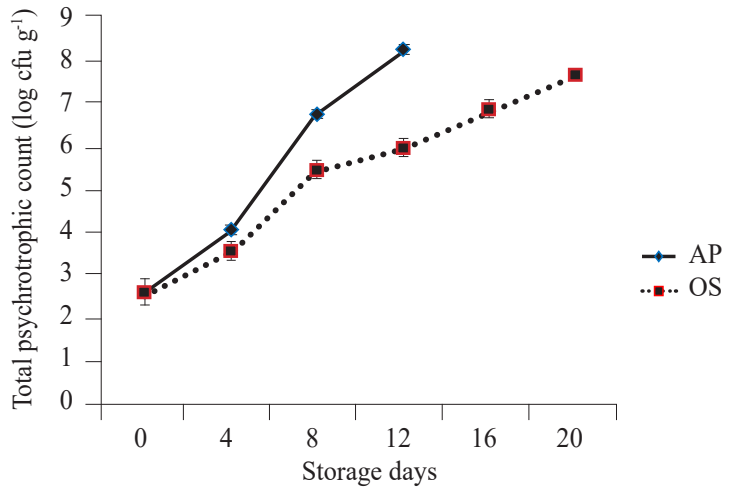

Fig. 9. Changes in the total psychrotrophic bacteria count ${ }^{*}$ of barracuda steaks during chilled storage. AP: Air pack, OS: Pack with oxygen scavenger. "Mean $\pm S D, n=3, p<0.01$

surpassed by AP and OS samples on $12^{\text {th }}$ and $20^{\text {th }}$ days of storage, which coincided with the sensory rejection of the samples. Similarly, by the combined use of $\mathrm{O}_{2}$ absorber and oregano oil, Mexis et al. (2009) observed an enhancement in the microbiological shelf life of rainbow trout fillets by 8 days.

Sensory analysis is one of the most important methods for judging the freshness and quality of fish. In the current work, appearance, colour, odour, taste, texture and flavour was assessed to evaluate the overall acceptability of the barracuda steak. Initially barracuda steak was very fresh with an overall acceptability score of 9 and had shiny appearance, seaweedy odour and firm and elastic texture, which altered with the storage period (Fig. 10). The results of the oragnoleptic evaluation (overall acceptability score) was well in agreement with the increase in the count of mesophilic bacteria and formation of volatile bases. Considering score of 5 as the lower limit of overall acceptability, the AP sample was

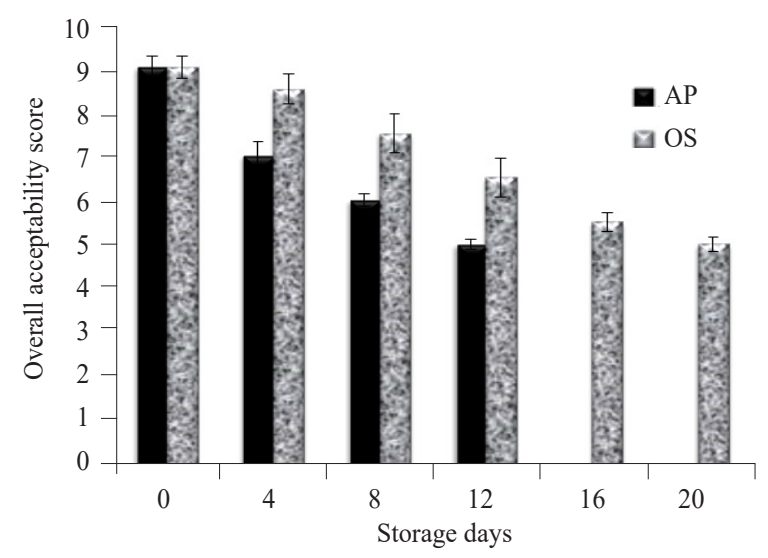

Fig. 10. Changes in the overall acceptability ${ }^{*}$ of barracuda steaks in different packs during chilled storage. AP: Air pack, OS: Pack with oxygen scavenger. ${ }^{*}$ Mean $\pm \mathrm{SD}, \mathrm{n}=3, \mathrm{p}<0.05$ 
acceptable only for 12 days while the samples packed under reduced oxygen atmosphere had a sensory shelf life of 20 days. The results suggested that the active reduced packaging atmosphere created by $\mathrm{O}_{2}$ scavenger could maintain the original oragnoleptic properties of fish, which are the first parameters assessed by consumers in grading fish and enhanced the shelf life of the barracuda steak stored at $0-2^{\circ} \mathrm{C}$ by 8 days.

Oxygen scavenger, the most popular active packaging technique can be used to reduce oxygen inside food packages to create a reduced oxygen atmosphere. The results of the present study clearly indicate that reduced oxygen concentration in the headspace of chilled stored barracuda fish steak pouches delayed lipid oxidation, volatile base formation and microbial spoilage action without affecting the sensory quality of fish leading to an extension in the storage life.

\section{Acknowledgements}

The authors would like to thank the Director, ICAR-CIFT, Kochi, India for providing facilities to carry out this work. The first author is thankful to the Director, ICAR-CIFE, Mumbai and the Head, FRHPHM Division, ICAR-CIFE for their encouragement. The authors also declare that there is no conflict of interest.

\section{References}

Alvarez, M. F. 2000. Active food packaging: Review. Food Sci. Technol. Int., 6(2): 97-108. https://doi.org/10.1177\% 2F108201320000600203.

AOCS 1989. Official methods and recommended practices of American Oil Chemists Society, $5^{\text {th }}$ edn. AOCS Champaign, USA.

Appendini, P. and Hotchkiss, J. H. 2002. Review of antimicrobial food packaging. Innov. Food Sci. Emerg. Technol., 3(2): 113-126. http://dx.doi.org/10.1016/S1466-8564(02) 00012-7.

Aubourg, S., Rey-Mansilla, M. and Sotelo, C. G. 1999. Differential lipid damage invarious muscle zones of frozen hake (Merluccius merluccius). Z. Lebensm. Unters. Forsch. A., 208(3): 189-193. https://doi.org/10.1007/s00 2170050400 .

Barthet, V. J., Gordon, V. and Dany, J. 2008. Evaluation of a colourimetric method for measuring the content of FFA in marine and vegetable oils. Food Chem., 111: 1064-1068. DOI: 10.1016/j.foodchem.2008.05.026.

Boselli, E., Caboni, M. F., Rodriguez-Estrada, M. T., Toschi, T. G., Daniel, M. and Lercker, G. 2005. Photoxidation of cholesterol and lipids of turkey meat during storage under commercial retail conditions. Food Chem., 91: 705-713. DOI: 10.1016/j.foodchem.2004.06.043.
Connell, J. J. 1995. Intrinsic quality. In: Control of fish quality. Fishing News Books/Blackwell Science, London, p. 5-36.

Connell, J. J. 1990. Control of fish quality, $3^{\text {rd }}$ edn. Fishing News Books Ltd., London.

Conway, E. J. 1962. Micro diffusion analysis and volumetric error, $5^{\text {th }}$ edn. Crosby Lockwood and Son Ltd., London.

Fan, W., Sun, J., Chen, Y., Qiu, J., Zhang, Y. and Chi, Y. 2009. Effects of chitosan coating on quality and shelf life of silver carp during frozen storage. Food Chem., 115: 66-70. DOI: 10.1016/j.foodchem.2008.11.060.

FAO 2014. The state of world fisheries and aquaculture 2014. Food and Agriculture Organisation, Rome, 62 pp.

Gonçalves, A., Mendes, R. and Nunes, M. L. 2004. Effect of oxygen absorber on the shelf life of gilthead sea bream (Sparus aurata). J. Aquat. Food Prod. Technol., 13(3): 49-59.

Hitching, A. D., Feng, P., Matkins, W. D., Rippey, S. R. and Chandler, L. A. 1995. Aerobic plate count. In: Tomlinsion, L. A. (Ed.), Bacteriological analytical manual, $18^{\text {th }}$ edn. AOAC International, Gaithersburg, MD, USA, p. 4.01-4.29.

Hurme, E. 2003. Detecting leaks in modified atmosphere packaging. In: Ahvenainen, R. (Ed.), Novel food packaging techniques. Woodhead Publishing Ltd., England and CRC Press, New York, 282 pp.

Meilgaard, M., Civille, G. V. and Carr, B. T. 1999. Sensory evaluation techniques, $3^{\text {rd }}$ edn. CRC Press, Boca Raton, USA, $387 \mathrm{pp}$.

Mexis, S. F., Chouliara, E. and Kontominas, M. G. 2009. Combined effect of an oxygen absorber and oregano essential oil on shelf life extension of rainbow trout fillets stored at $4^{\circ}$ C. Food Microbiol., 26: 598-605. doi: 10.1016/j. fm.2009.04.002.

Mohan, C. O., Ravishankar, C. N., Srinivasa Gopal, T. K., Lalitha, K. V. and Asok Kumar, K. 2010. Effect of reduced oxygen atmosphere and sodium acetate treatment on the microbial quality changes of seer fish (Scomberomorus commerson) steaks stored in ice. Food Microbiol., 27: 526534. DOI: 10.1016/j.fm.2010.01.005.

Mohan, C. O., Ravishankar, C. N., Srinivasa Gopal, T. K. and Ashok Kumar, K. 2009. Nucleotide breakdown products of seer fish (Scomberomorus commerson) steaks stored in $\mathrm{O}_{2}$ scavenger packs during chilled storage. Innov. Food Sci. Emerg. Technol., 10: 272-278. DOI: 10.1016/j. ifset.2008.11.012.

Mohan, C. O., Ravishankar, C. N. and Srinivasagopal, T. K. 2008. Effect of $\mathrm{O}_{2}$ scavenger on the shelf-life of catfish (Pangasius sutchi) steaks during chilled storage. J. Sci. Food Agri., 88: 442-448. doi.org/10.1002/jsfa.3105. 
Ozdemir, M. and Floros, J. D. 2004. Active food packaging technologies. Crit. Rev. Food Sci. Nutr., 44: 185-193. doi.org/10.1080/10408690490441578.

Pastoriza, L., Sampedro, G., Herrera, J. J. and Cabo, M. L. 1996. Effect of modified atmosphere packaging on shelf life of iced fresh hake slices. J. Sci. Food Agri., 71: 541-547. https://doi.org/10.1002/(SICI)1097-0010(199608)71:4<5 41::AID-JSFA615>3.0.CO;2-H.

Pereira de Abreu, D. A., Cruz, J. M. and Paseiro Losada, P. 2012. Active and intelligent packaging for the food industry. Food Rev. Int., 28(2): 146-187. doi.org/10.1080/8755912 9.2011.595022.

Ravishankar, C. N., Lalitha, K. V., Leema Jose, Manju, S. and Gopal, T. K. S. 2008. Effect of packaging atmosphere on the microbial attributes of pearlspot (Etroplus suratensis Bloch) stored at $0-2^{\circ} \mathrm{C}$. Food Microbiol., 25: 518-528.

Ruiz-Capillas, C. and Moral, A. 2005. Sensory and biochemical aspects of quality of whole bigeye tuna (Thunnus obesus) during bulk storage in controlled atmospheres. Food Chem., 89(3): 347-354. DOI: 10.1016/j.foodchem.2004.02.041.

Sivertsvik, M., Jeksrud, W. K. and Rosnes, J. T. 2002. A review of modified atmosphere packaging of fish and fishery products - significance of microbial growth, activities and safety. Int. J. Food Sci. Technol., 37(2): 107-127. https:// doi.org/10.1046/j.1365-2621.2002.00548.x.

Stiles, M. E. 1991. Scientific principles of controlled/modified atmosphere packaging. In: Ooraikul, B. and Stiles, M. E. (Eds.), Modified atmosphere packaging of food, Ellis Horwood, London, p. 18-25.

Suppakul, P., Miltz, J. M., Sonneveld, K. and Bigger, S. W. 2003. Antimicrobial properties of basil and its possible application in food packaging. J. Agri. Food Chem., 51(11): 3197-3207. DOI: 10.1021/jf021038t.

Tarladgis, B. G., Watts, B. M., Yonathan, M. and Dugan, L. J. R. 1960. Distillation method for the determination of malonaldehyde in rancid foods. J. Am. Oil Chem. Soc., 37(1): 44-48. http://dx.doi.org/10.1007/BF02630824.

Townley, R. R. and Lanier, T. 1981. Effect of early evisceration on the keeping quality of Atlantic croaker (Micropogon undulates) and grey trout (Cynoscion regalis) as determined by subjective and objective methodology. J. Food Sci., 46: 863-867. https://doi.org/10.1111/j.1365-2621.1981. tb15367.x. 